\title{
Yield, Quality and Stability Evaluation of Some Sugar beet Varieties in Relation
} to Locations and Sowing dates Aly, E. F. A. ${ }^{1}$ and Soha, R. A. Khalil. ${ }^{2}$

${ }^{1}$ Variety Maintenance Res. Dept.

${ }^{2}$ Sugar Technol. Dept., SCRI, Agric. Res. Center, Giza, Egypt

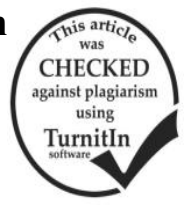

\section{ABSTRACT}

Two separate field experiments were carried out in two sowing dates at each of El-Nubaria (latitude of $30^{\circ} 37^{\backslash} \mathrm{N}$ and longitude of $42^{0} 07^{`} \mathrm{E}$, and elevation of $34 \mathrm{~m}$ above sea level), El-Buhira Governorate and Tamia (latitude of $29^{\circ} 18^{\backslash} \mathrm{N}$ and longitude of $30^{\circ} 25^{\backslash} \mathrm{E}$ and elevation of $-13 \mathrm{~m}$ beyond sea level), El-Fayoum Governorate, Egypt in 2013/2014 and 2014/2015 seasons to evaluate eight sugar beet varieties for its performance for economic characteristics and stability. The sugar beet varieties were; Cesira, Univeres, Esperanza and Yaman as monogerm seeds as well as Carola, Oscar poly, Panther and Farida as multigerm seeds, and sowing dates were; the $1^{\text {st }}$ week of both October and November in the first and second seasons respectively. Every experiment of location was carried out in strip-plot design with three replications. A stability analysis was done to test the varieties to find out the most stable one over the eight environments under this study. The obtain results show that growing sugar beet at Tamia site resulted in highest values of root fresh weight/plant, root yield/fed as well as the percentages of sucrose, corrected sugar and quality index, while, at El-Nubaria, the highest value of corrected sugar yield/fed was obtained.Sugar beet planted on October had the higher values of root fresh weigh/plant, root and sugar yields/fed, as well as the percentages of sucrose, corrected sugar and quality index and less significant impurities compared with that sown on November.Oscar poly variety significantly surpassed of root fresh weigh/plant and root yield/fed, while Cesira variety surpassed of corrected sugar yield, sucrose $\%$, corrected sugar $\%$ and quality index $\%$. Farida had the lowest response for potassium at ElNubaria, while Panther had the lowest for Na at El-Fayoum. Oscar poly was significantly higher in root fresh weigh/plant, and root and sugar yields/fed in October planting. Under this work, it could be recommended that Oscar poly, Panther and Farida varieties were the most high and stable root yield-type. Meanwhile, Cesira, Univeres and Carola were the most suitable ones for sucrose $\%$ and sugar yield-type and were useful for beet sugar manufacture earlier in the crushing season.

Keywords: sugar beet varieties, sowing dates, locations, GxE interaction, stability analysis.

\section{INTRODUCTION}

Sugar beet is considered one of important winter sugar crop in Egypt. So, it is preferable to evaluate sugar beet verities under Egyptian conditions to select the best ones characterized with high yield and quality traits to decrease the Egyptian gap from sugar (Al-Labbody, 2012). Walter, (1987) discussed the important of the selection of locations for the evaluation of quantitative characters is an important decision for sugar beet breeder, and involves a number of considerations. Also, he found that wide fluctuations in the rank performance of genotypes at test locations suggest that it may be desirable to develop and/or selection the best genotypes for different locations through independent selection. In this connection, Kristek et al. (1997) establish that the influence of locations was very high in root yield, sugar content and sugar yield between locations. Aly et al. (2006) cleared that Kafr El-Sheikh location gave the greatest value of root weight, extractable sugar $\%$, quality $\%$ and yields of root and sugar/fed compared to Al-Fayoum location. The highest values of sodium $\%$ and potassium were produced from Al-Fayoum location.

Sowing date has an active role on growth, yield and quality characteristics of sugar beet under the environmental conditions of Egypt; there is a general agreement that early planting of sugar beet during September-October results in highest sucrose $\%$ as well as root and sugar yields per unit area (Nasr and Abd ElRazek 2008). Important environmental variables that determine the beginning of sugar beet growing season are temperature, light precipitation and soil moisture (Petkeviciene, 2009). Other studies found that planting sugar beet through October markedly increased weight of roots, sugar content as well as root and sugar yields, compared with beets sown in November (Ghareeb,
Zeinab et al. 2013 and Mahdi, et al. 2013). Ntwanai and Tuwana 2013 and Hossain, Ferdous et al. 2015) reported that early sown sugar beet matured early and quality development parameters (sucrose $\%$ and quality index). Inversely, impurities ( $\mathrm{K}, \mathrm{Na}$, and alpha amino $\mathrm{N})$ varied attributed to planting dates.

Several studies either in Egypt or overseas reported the importance of selected or/and evaluated varieties for increasing sugar productivity as well as showed the differences between sugar beet varieties in yield and quality in many environmental condition, i.e., location and sowing dates. Hozayn, et al. (2013) cleared that individual variability of different varieties might be attributed to their genetic constituents and their capacity to benefit from the environmental factors, which enable them to acclimatize and attain better yield and quality parameters. Ntwanai and Tuwana (2013) stated that planting date $\mathrm{x}$ varieties and location $\mathrm{x}$ varieties interactions had a significant effect on sugar and root yields and sugar content as well as impurities of sugar beet cultivars. Ghareeb, Zeinab et al., (2013) found that Pleno, Samba, Sultan and Farida sugar beet genotypes had the highest root and sugar yields at early sowing dates in October than that in November. Kaloi, et al. (2014) showed that locations $\mathrm{x}$ varieties interaction were highly significant in yields and quality parameters. Hossain, Ferdous et al. (2015) mentioned that root yield of the three genotypes (Cauvery, Shubhra and EB0616) significantly decreased with the advancement of sowing dates from 1 November to 15 December.

When genotypes are compared in different environments (predictable or/and unpredictable), their performance relative to each other may not be the same. One genotype may have the highest yield in some environments and a second genotype may excel in other. Changes in the relative performance of 
genotypes across different environments are referred to as genotype $\mathrm{x}$ environment interaction (GEI). One of the essential final stages in the most applied plant breeding programs was an evaluation of genotypes across diversified environments years and locations (walter, 1987). Kang et al., (1991) concluded that farmers would have a greater risk of pain yield losses, when a variety is selected only on the basis of mean yield alone than when selection is based on yield and stable performance. It is a fact that farmers would prefer to use a high-yielding cultivar that exhibits temporal difference and might be pleasant to give up some yield if they are sure, to some degree that a cultivar would produce consistently from year to year. Yield stability statistic $\left(\mathrm{YS}_{\mathrm{i}}\right)$ was calculated using STABLE computer program (a DOS-version of computer program for calculating stability and yieldstability statistics) modified by Kang and Magari (1995) in this program should be useful for selecting high-yielding, stable genotypes. Also, those successful new tested varieties must show high performance for yield and other essential agronomic traits. Immediate selection for yield and yield stability in sugar beet by Kang's computer program including $\delta_{i}^{2}, S_{i}{ }_{i}$ and $\mathrm{YS}_{\mathrm{i}}$ stability parameters has been showed by various authors as Shalaby (2003); Aly (2006); Shalaby et al. (2007); Khalil, Soha (2010) and AI-Jbawi et al. (2016).

The present study was performed to evaluate the effect of macro environmental conditions, i.e. seasons, location and sowing date on yield and quality of eight sugar beet genotypes, to determine the magnitude of genotypes $\mathrm{x}$ environment interaction and to measure stability for root and sugar yields and sugar content of the genotypes; and then to find out the best stable sugar beet variety/varieties and appropriate sowing date in each of Nubaria and Fayoum to get the highest yield and quality traits.

\section{MATERIALS AND METHODS}

Two separate field experiments were carried out in two sowing dates at each of El-Nubaria (latitude of $30^{\circ} 37^{\backslash} \mathrm{N}$ and longitude of $42^{\circ} 07^{\wedge} \mathrm{E}$, and elevation of Table 1. Soil properties of the two experimental sites

\begin{tabular}{|c|c|c|c|c|c|c|c|c|c|c|c|}
\hline \multirow{2}{*}{\multicolumn{2}{|c|}{ Soil sample }} & \multicolumn{3}{|c|}{ Particle size distribution } & \multirow{2}{*}{$\begin{array}{c}\text { Textural } \\
\text { Class }\end{array}$} & \multicolumn{3}{|c|}{ Available Nutrients } & \multirow{2}{*}{$\underset{\text { dSm }^{-1}}{\text { E.C }}$} & \multirow{2}{*}{$\underset{\%}{\text { O.M }}$} & \multirow{2}{*}{$\underset{\text { Soil }}{\text { pH }}$} \\
\hline & & $\underset{\%}{\text { Sand }}$ & $\begin{array}{l}\text { Silt } \\
\%\end{array}$ & $\begin{array}{l}\text { Clay } \\
\%\end{array}$ & & & (ppm) & $\mathbf{K}$ & & & \\
\hline $3 / 1$ & El-Fayoum & 10.0 & 4.5 & 85.5 & $\mathrm{Cla}$ & 38.18 & 2.59 & 105.2 & 0.46 & 1.99 & 8.1 \\
\hline $2015 / 14$ & El-Nubaria & 90.8 & 7.2 & 2.0 & Sandy & 25.62 & 2.30 & 97.2 & 0.49 & 1.1 & 8.3 \\
\hline $2014 / 15$ & El-Fayoum & 10.1 & 7.9 & 82.0 & Clay & 40.48 & 2.81 & 128.3 & 0.57 & 1. & 8.0 \\
\hline $2014 / 15$ & El-Nubaria & 91 & 7. 1 & 1.9 & Sandy & 28.12 & 2.10 & 89.8 & 0.44 & 1.19 & 8.4 \\
\hline
\end{tabular}

Table 2. The temperature degrees of El-Nubaria and El-Fayoum locations

\begin{tabular}{|c|c|c|c|c|c|c|c|c|c|c|c|c|}
\hline \multirow{3}{*}{$\begin{array}{l}\text { Year } \\
\text { Months }\end{array}$} & \multicolumn{6}{|c|}{$2013 / 2014$ season } & \multicolumn{6}{|c|}{ 2014/2015 season } \\
\hline & \multicolumn{3}{|c|}{ El-Nubaria } & \multicolumn{3}{|c|}{ El-Fayoum } & \multicolumn{3}{|c|}{ El-Nubaria } & \multicolumn{3}{|c|}{ El-Fayoum } \\
\hline & Mx. & Min. & Av. & Mx. & Mín. & Av. & Mx. & Min. & Av. & Mx. & Min. & Av. \\
\hline October & 31.0 & 17.3 & 24.2 & 32.8 & 18.0 & 25.4 & 32.5 & 17.3 & 24.9 & 33.6 & 18.6 & 26.1 \\
\hline November & 26.0 & 12.7 & 19.4 & 28.1 & 16.0 & 21.6 & 27.0 & 12.7 & 19.9 & 28.7 & 16.6 & 22.4 \\
\hline December & 20.0 & 8.8 & 14.4 & 20.2 & 11.0 & 15.6 & 20.4 & 9.2 & 14.8 & 22.2 & 11.1 & 16.7 \\
\hline January & 20.0 & 6.6 & 13.3 & 20.1 & 10.0 & 15.1 & 21.0 & 7.6 & 14.3 & 21.1 & 10.0 & 15.6 \\
\hline February & 22.0 & 5.9 & 14.0 & 20.2 & 10.0 & 15.1 & 22.2 & 5.9 & 14.1 & 23.2 & 9.7 & 16.5 \\
\hline March & 24.0 & 8.4 & 16.2 & 24.2 & 10.0 & 17.1 & 25.0 & 8.4 & 16.7 & 27.6 & 10.2 & 18.9 \\
\hline April & 28.0 & 12.0 & 20.0 & 29.1 & 12.0 & 20.6 & 28.6 & 13.1 & 20.9 & 32 & 12.2 & 22.4 \\
\hline May & 33.9 & 18.9 & 26.4 & 34.8 & 22.7 & 28.8 & 34.2 & 18.6 & 26.4 & 36.8 & 23.5 & 30.2 \\
\hline Average & 25.6 & 11.3 & 18.5 & 26.1 & 13.7 & 19.9 & 26.4 & 11.6 & 19.0 & 28.2 & 14.0 & 21.1 \\
\hline
\end{tabular}

Source: Agro-meteorological station, Agric. Res. Center, Giza, Egypt, Temp. = Temperature $\left(C^{0}\right)$. Max. $=$ Maximum. Min. $=$ Minimum. Av. = Average. 
The recorded data:

At harvest, plants of three inside ridges were uprooted, topped and weighed to determine:

1. Root fresh weight ( $\mathrm{g} / \mathrm{plant})$, determined from randomly samples of 10 roots were taken from each plots in the two locations.

Juice quality and chemical constituents:

Quality traits were determined in Beet Sugar Laboratory at Alexandria Sugar Factory, Egypt. Impurities of juice, in terms of Sodium (Na) and Potassium (K) concentrations were estimated as meq $/ 100 \mathrm{~g}$ beet according to the procedures of Sugar Company, by Automated Analyzer, as described by Brown and Lilliand (1964). Alpha-amino-N was determined using Hydrogenation method according to Carruthers, et al. (1962).

2. Sucrose percentage ( $\mathrm{Pol} \%)$ was estimated in fresh samples of sugar beet roots, using Saccharometer according to the method described in A.O.A.C, (2005).

3. Corrected sugar \% was calculated using the following equation according to Cooke and Scott (1993):

4. Corrected sugar $\%=$ Pol $\%-0.343 *(\mathrm{~K}+\mathrm{Na})-\alpha$ amino $\mathrm{N} *(0.0939)-0.29$.

5. Juice quality index (QI\%) was calculated according to Cooke and Scott (1993) using the following equation:

$\mathrm{QI} \%=$ Corrected sugar $\% * 100 / \mathrm{Pol} \%$.

6 . Root yield $(\mathrm{t} / \mathrm{fed})$, determined from three inside ridges from all plots in the two locations (uprooted, topped and weighed).

7. Corrected sugar yield $(\mathrm{t} / \mathrm{fed})$, which was calculated according to the following equation: Corrected sugar yield $(\mathrm{t} / \mathrm{fed})=$ root yield $(\mathrm{t} /$ fed $) \mathrm{x}$ corrected sugar $\%$

Statistical analysis:
All obtained data were statistically analyzed according to the technique of analysis of variance (ANOVA) for the strip-plot design for each experiment (location), and then combined analysis was used between location experiments as published by Gomez and Gomez (1984) by using (MSTAT-C) computer software package. Least significant differences (LSD) method was used to test the differences between treatment means at 5\% level of probability as described by Snedecor and Cochran (1980). Plot means were used for statistical analysis. Data from each macro environment (combinations of years and locations) were analyzed. In the combined analysis across environmental effect was assumed to be fixed. Combined analysis estimates of the components of variation in each mean square were calculated to evaluate the magnitude of the different effects. The present data were subjected to yield stability analysis by yield stability index (YSi) as outlined by Kang and Magari (1995). Eight environments (Two seasons x two locations $\mathrm{x}$ two sowing dates) were analyzed by Kang's computer program. The studied traits were root and corrected sugar yields/fed and corrected sugar $\%$.

\section{RESULTS AND DISCUTIONS}

Combined data in Table 3 show that all mentioned traits were significantly affected by locations except alpha amino-N. Sugar beet cultivated in ElFayoum exceeded that in Nubaria in RFW and RY by $79 \mathrm{~g} /$ plant and $0.463 \mathrm{t} / \mathrm{fed}$, respectively, while CSY in El-Fayoum surpassed that in Nubaria by $0.019 \mathrm{t} / \mathrm{fed}$. whereas, sugar beet sown at El-Nubaria was significantly higher than that El-Fayoum by $0.35 \%$, $0.35 \%$ and $0.23 \%$ in sucrose, $\mathrm{CS} \%$ and $\mathrm{QI} \%$, respectively.

Table 3. Combined analysis over two successive seasons 2013/14 and 2014/15 for some sugar beet characters affected location, sowing date and varieties.

\begin{tabular}{|c|c|c|c|c|c|c|c|c|c|}
\hline \multirow{2}{*}{ Main effects } & \multirow{2}{*}{ RFW } & \multirow{2}{*}{$\mathbf{R Y}$} & \multirow{2}{*}{ Sucrose \% } & \multicolumn{3}{|c|}{ Impurities (meq/100 g beet) } & CS\% & \multirow{2}{*}{ QI\% } & CSY \\
\hline & & & & $\begin{array}{c}\alpha \text {-amino } \mathbf{N} \\
\text { Locations (L }\end{array}$ & $\mathbf{K}$ & $\mathbf{N a}$ & & & \\
\hline EL-Nubariea & 1088 & 25.275 & 17.52 & 0.75 & 3.36 & 1.48 & 15.50 & 88.41 & 3.919 \\
\hline EL-Fayoum & 1157 & 25.738 & 17.17 & 0.76 & 3.43 & 1.41 & 15.15 & 88.18 & 3.900 \\
\hline$F$ test & & & $*$ & NS & & & & & \\
\hline \multicolumn{10}{|l|}{ Sowing dates $(S)$} \\
\hline Oct. $1^{\text {st }}$ & 1147 & 26.332 & 17.86 & 0.78 & 3.32 & 1.40 & 15.88 & 88.88 & 4.176 \\
\hline Nov. $1^{\text {st }}$ & 1099 & 24.680 & 16.83 & 0.73 & 3.48 & 1.49 & 14.77 & 87.71 & 3.642 \\
\hline F test & $*$ & $*$ & $*$ & $*$ & $*$ & $*$ & $*$ & $*$ & $*$ \\
\hline \multicolumn{10}{|l|}{ Varieties (V) } \\
\hline Cesira & 990 & 24.707 & 18.42 & 0.71 & 3.34 & 0.71 & 16.47 & 89.40 & 4.071 \\
\hline Univeres & 1127 & 25.722 & 17.36 & 0.78 & 3.43 & 0.78 & 15.33 & 88.28 & 3.949 \\
\hline Esperanza & 1052 & 24.592 & 17.42 & 0.75 & 3.38 & 0.75 & 15.36 & 88.20 & 3.785 \\
\hline Yaman & 1082 & 24.958 & 17.82 & 0.77 & 3.41 & 0.77 & 15.80 & 88.64 & 3.944 \\
\hline Carola & 1150 & 25.517 & 17.75 & 0.76 & 3.40 & 0.76 & 15.75 & 88.71 & 4.021 \\
\hline Oscarpoly & 1200 & 26.434 & 16.52 & 0.76 & 3.36 & 0.76 & 14.50 & 87.76 & 3.839 \\
\hline Panther & 1192 & 26.191 & 16.67 & 0.75 & 3.40 & 0.75 & 14.64 & 87.81 & 3.840 \\
\hline Farida & 1190 & 25.930 & 16.81 & 0.78 & 3.47 & 0.78 & 14.73 & 87.58 & 3.824 \\
\hline LSD at 0.05 & 23 & 0.325 & 0.23 & 0.03 & 0.07 & 0.03 & 0.23 & 0.24 & 0.078 \\
\hline $\mathrm{L} \times \mathrm{S}$ & NS & NS & NS & NS & $*$ & $*$ & NS & NS & NS \\
\hline $\mathrm{L} \times \mathrm{V}$ & NS & NS & NS & NS & $*$ & * & NS & NS & NS \\
\hline $\mathrm{S} \times \mathrm{V}$ & * & * & NS & NS & NS & NS & NS & NS & $*$ \\
\hline $\mathrm{L} \times \mathrm{S} \times \mathrm{V}$ & NS & NS & NS & NS & NS & NS & NS & NS & NS \\
\hline
\end{tabular}

RFW: Root fresh weight (g); RY: Root yield (t/fed); CS\%: Corrected sugar\%, QI\%: Quality index\% and CSY: Corrected sugar yield $(\mathbf{t} / \mathbf{f e d})$ 
These results may be due to higher temperatures degrees at El-Fayoum than that at El Nubariab, which was favourable for better dry matter accumulation in the storage roots on growth period. Inversely action of high temperatures of sugar translocation and accumulation are at ripening stage in roots at El-Fayoum. These results are similar with those reported by Ramazan (2002), who found strong positive correlation between accumulated sugar content in roots and low temperature in ripening stage of sugar beet. This observation coincide with those found by Kristek et al. (1997) and Aly, et al., (2006)

In the same Table, the results manifest that sowing sugar beet earlier on October $1^{\text {st }}$ significantly increased RFW, RY and CSY by $48 \mathrm{~g}, 1.652 \mathrm{t} / \mathrm{fed}$ and $0.573 \mathrm{t} / \mathrm{fed}$, respectively as compared to that sown it on November $1^{\text {st }}$. Sowing sugar beet on October $1^{\text {st }}$ significantly increased by $1.03 \%, 1.11 \%$ and $1.17 \%$ in sucrose $\%, \mathrm{CS} \%$ and $\mathrm{QI} \%$, successively compared to that sown on November $1^{\text {st }}$. These results are in agreement with those obtained by Mahdi et al. (2013) and Nasr and Abd El-Razek (2008).

The combined data in Table 3 showed that all tested sugar beet varieties were significantly differed in RFW, RY and CSY. Oscar poly variety surpassed Cesira in RFW by $210 \mathrm{~g}$ and Esperanza in RY by 1.842 $\mathrm{t} /$ fed. On the other hand, Cesira variety out-yielded Farida in CSY by $0.247 \mathrm{t} / \mathrm{fed}$. The superiority of Cesira variety in CSY may be attributed to its superiority in sucrose $\%$ and corrected sugar $\%$ with lowest values of the impurities ( $\mathrm{K}, \mathrm{Na}$ and $\mathrm{N}$ ) in juice (Tables $4 \& 5$ ). These results may be basically due to the genetic structures of sugar beet varieties. These results are in harmony with those achieved by Hozayn et al. (2013) and Hossain, Ferdous et al. (2015).

Table 4. Significant interaction between locations and sowing dates affected potassium and sodium in combined analysis over two seasons 2013/14 and 2014/15.

\begin{tabular}{llcc}
\hline Locations (L) & $\begin{array}{c}\text { Sowing date } \\
\text { (s) }\end{array}$ & $\begin{array}{c}\text { (meq/100 g beet) } \\
\text { K }\end{array}$ & $\begin{array}{c}\text { Na } \\
\text { EL-Nubariea }\end{array}$ \\
& $1^{\mathrm{St}}$ October & 3.27 & 1.42 \\
& $1^{\text {st }}$ November & 3.46 & 1.54 \\
EL-Fayoum & $1^{\text {st }}$ October & 3.36 & 1.38 \\
LSD at 0.05 & $1^{\text {st }}$ November & 3.50 & 1.44 \\
& & 0.02 & 0.03 \\
\hline
\end{tabular}

Data in Table 4 indicate that location $\mathrm{x}$ sowing date interaction had a significant effect on potassium and sodium contents in sugar beet roots. Sugar beet sown on the first week of October compared to November at Tamia site recorded the lowest significant variance by 0.14 and $0.06 \mathrm{meq} / 100$ beet for potassium and sodium successively than sugar beet sown at ElNubaria.

Combined analysis in Table 5 show all varieties differed significantly in $\mathrm{K}$ and $\mathrm{Na}$ that affected by locations $\mathrm{x}$ sowing dates. Sown Farida at El-Nubaria gave lower value of $\mathrm{K}$ compared to that sown at Tamia. On the other hand, sown Panther at El-Fayoum achieved the lowest value of $\mathrm{Na}$, while Farida had the highest compared to that sown at El- Nubaria. These results might be referred to the increment of $\mathrm{K}$ element in clay soil at El-Fayoum more than El-Nubaria (Table 1). These results are in agreement with those obtained by (Ntwanai and Tuwana, 2013 and Kaloi, et al., 2014).

Table 5. Effect of the significant interaction between locations and varieties on potassium and sodium in combined analysis over two seasons 2013/14 and 2014/15.

\begin{tabular}{lccc}
\hline Location (L) & \multicolumn{3}{c}{ Varieties (V)K (meq/100Na ( $\mathbf{m e q} / \mathbf{1 0 0}$} \\
\hline & Cesira & 3.33 & 1.30 \\
& Univeres & 3.31 & 1.50 \\
EL-Nubariea & Esperanza & 3.34 & 1.58 \\
& Yaman & 3.39 & 1.40 \\
& Carola & 3.41 & 1.45 \\
& Oscarpoly & 3.35 & 1.49 \\
& Panther & 3.37 & 1.52 \\
& Farida & 3.41 & 1.61 \\
\hline & Cesira & 3.35 & 1.31 \\
& Univeres & 3.54 & 1.37 \\
& Esperanza & 3.41 & 1.52 \\
& Yaman & 3.42 & 1.45 \\
& Carola & 3.39 & 1.31 \\
& Oscarpoly & 3.37 & 1.46 \\
& Panther & 3.43 & 1.40 \\
& Farida & 3.53 & 1.47 \\
& LSD at 1 & 0.09 & 0.08 \\
\hline
\end{tabular}

The results in Table 6 indicate that sowing dates $\mathrm{x}$ varieties interaction significantly affected RFW, RY and CSY. Concerning RFW, the results showed that Cesira and Yaman varieties were insignificantly affected by sowing dates, while the other tested varieties produced significantly higher RFW under the earlier sowing date. As for RY, although all varieties recorded higher RY under conditions of earlier sowing date, it was noticed that the increments in RY of Oscar poly and Yaman varieties (2.359 and $0.669 \mathrm{t} / \mathrm{fed})$ was distinguished when it were sown on October compared to its values under November sown.

Table 6. Effect of the significant interaction between sowing dates and varieties on some traits in combined analysis over two seasons 2013/14 and 2014/15.

\begin{tabular}{cccccc}
\hline $\begin{array}{c}\text { Sowing } \\
\text { dates } \\
\text { (S) }\end{array}$ & $\begin{array}{c}\text { Varieties } \\
\text { (V) }\end{array}$ & $\begin{array}{c}\text { Root } \\
\text { fresh } \\
\text { weight } \\
\text { (g) }\end{array}$ & $\begin{array}{c}\text { Root } \\
\text { yield } \\
\text { (t/fed) }\end{array}$ & $\begin{array}{c}\text { Corrected } \\
\text { sugar } \\
\text { yield } \\
\text { (t/fed) }\end{array}$ & $\begin{array}{c}\text { Na } \\
\text { (meq/100g } \\
\text { beet) }\end{array}$ \\
\hline & Cesira & 987 & 25.124 & 4.269 & 1.25 \\
& Univeres & 1167 & 26.877 & 4.269 & 1.37 \\
$1^{\text {st }}$ Oct. & Esperanza & 1084 & 25.761 & 4.113 & 1.50 \\
& Yaman & 1084 & 25.290 & 4.137 & 1.34 \\
& Carola & 1169 & 26.019 & 4.249 & 1.37 \\
& Oscarpoly & 1242 & 27.614 & 4.126 & 1.40 \\
& Panther & 1223 & 27.148 & 4.117 & 1.43 \\
& Farida & 1219 & 26.827 & 4.130 & 1.54 \\
\hline \multirow{5}{*}{$1^{\text {st }}$ Nov. } & Cesira & 992 & 24.290 & 3.873 & 1.36 \\
& Univeres & 1086 & 24.568 & 3.628 & 1.50 \\
& Esperanza & 1020 & 23.422 & 3.458 & 1.60 \\
& Yaman & 1080 & 24.625 & 3.752 & 1.50 \\
& Carola & 1131 & 25.016 & 3.794 & 1.39 \\
& Oscarpoly & 1158 & 25.255 & 3.552 & 1.55 \\
& Panther & 1161 & 25.234 & 3.562 & 1.50 \\
& Farida & 1162 & 25.033 & 3.519 & 1.54 \\
LSD at 0.05 & 32 & 0.460 & 0.109 & 0.08 \\
\hline
\end{tabular}

Root fresh weight (g): RFW, Root yield (t/fed): RY, Corrected sugar yield (t/fed): CSY

Regarding to CSY, all varieties recorded highest response CSY with sowing date in October. It was observed that the increase in CSY of Esperanza (0.655 $\mathrm{t} / \mathrm{fed}$ ) was great when it was sown in October compared to its value under conditions of Nov $1^{\text {st }}$. Also, it is 
noticed that Cesira showed the lowest response under the studied sowing dates. These results are in agreement with those obtained by (Ghareeb, Zeinab et al., 2013 and Mahdi et al., 2013). All the other interactions among the studied factors had insignificant influence on the abovementioned traits.

Stability analysis of root and corrected sugar yields/fed, and corrected sugar\% was suggested by the computer program of Kang and Magari (1995).

The data in Table 7 explains that evaluated means squares of genotypes $(\mathrm{G})$ and $(\mathrm{G} \times \mathrm{E})$ interaction were less than Environments (E) for all traits except corrected sugar $\%$ mean square of $(\mathrm{G})$ which was higher than (E) throughout the eight different environments. The mean squares of genotypes and environments were highly significant in all the studied traits. The GxE was found to be significant for root and corrected sugar yields/fed, while means square of the other traits were insignificant.

Table 7.Mean squares of ANOVA stability analysis for some sugar beet characters throughout 8 environments of eight sugar beet genotypes.

\begin{tabular}{lcccc}
\hline S.O.V & D.F & $\begin{array}{c}\text { Root } \\
\text { yield } \\
\text { (t/fed) }\end{array}$ & $\begin{array}{c}\text { Correct } \\
\text { ed } \\
\text { sugar } \\
\text { yield } \\
\text { (t/fed) }\end{array}$ & $\begin{array}{c}\text { Corrected } \\
\text { sugar\% }\end{array}$ \\
\hline Total $(\mathrm{G}+\mathrm{E}+(\mathrm{GxE}))$ & 63 & &
\end{tabular}

\begin{tabular}{lccccc}
\hline Total $(\mathrm{G}+\mathrm{E}+(\mathrm{GxE}))$ & 63 & - & - & - \\
Genotypes & $(\mathrm{G})$ & 7 & $11.426 * *$ & $0.253^{* *}$ & $10.995 * *$
\end{tabular}

Environments

(year x location x $7 \quad 20.432 * * 1.992 * * \quad 9.627 * *$

sowing date) $\mathrm{E}$.

Interaction (G x E.) $490.923 * * \quad 0.027 * \quad 0.150 \mathrm{~ns}$

$\begin{array}{lllll}\text { Heterogeneity } & 7 & 2.595 * * & 0.065 * * & 0.105 \mathrm{~ns}\end{array}$

(linear)

$\begin{array}{lcccc}\text { Residual (non linear) } & 42 & 0.644 * * & 0.021 * * & 0.157 \mathrm{n} \\ \text { Pooled error } & 112 & 0.324 & 0.018 & 0.165\end{array}$

*and** significant at the 0.05 and 0.01 probability levels of significant, respectively

The partition of the GxE variance into its components, heterogeneity (linear response or nonadditively) and residual (non linear) of the three traits were also shown in Table 7. Significant means square of Genotypes for these traits indicate that genotypes are genetically differs in performance from environment to another.

In the same table, data cleared that the residual (pooled deviation) was significant for root and corrected sugar yields/fed. The residual represents deviation after the differential effect of a covariate (differential soil fertility, cultural practices, insect or disease incidence, or climate conditions at different environments) has been removed. The presence of mentioned GxE interactions are based only on genotype means was not dependable. Similar results had obtained by (Aly, 2006; Shalaby et al. 2007; and Al-Jbawi et al. 2016).

Data in Table 8 show the significant of genotype $\times$ environmental interactions were calculated by stability statistic parameter $\left(\mathrm{YS}_{\mathrm{i}}\right)$ for the eight genotypes as described by Kang and Magari (1995).

According to Kang's stability statistic parameter, $\mathrm{YS}_{\mathrm{i}}$ based on selection differentiate the eight genotypes regarding that in root yield, and identified four stable and high yielding sugar beet genotypes and descending ordered $\left(\mathrm{YS}_{\mathrm{i}}>\Sigma \mathrm{YS}_{\mathrm{i}} / \mathrm{t}\right)$ as Panther followed by Oscar poly, Farida and Univeres with means root yield of 26.191, 26.434, 25.931 and $25.722 \mathrm{t} /$ fed., respectively. Also, it could be recognized that the three sugar beet genotypes Cesira, Univeres and Carola could be selected as superior genotypes in corrected sugar yield/fed according their $\mathrm{YS}_{\mathrm{i}}>\Sigma \mathrm{YSi} / \mathrm{t}$.

Table 8. Means performance of some sugar beet characteristics and stability statistics, based on variance parameters models, for eight sugar beet varieties grown under eight environments.

\begin{tabular}{lccccccc}
\hline Genotypes & \multicolumn{2}{c}{$\begin{array}{c}\text { Root yield } \\
\text { (t/fed) }\end{array}$} & \multicolumn{2}{c}{$\begin{array}{c}\text { Corrected } \\
\text { sugar yield } \\
\text { (t/fed) }\end{array}$} & \multicolumn{2}{c}{$\begin{array}{c}\text { Corrected } \\
\text { sugar\% }\end{array}$} \\
& Mean & YSi & Mean & YSi & Mean & YSi \\
\hline Cesira & $24.707 \mathrm{e}$ & -9 & $4.071 \mathrm{a}$ & $3+$ & $16.47 \mathrm{a}$ & $11+$ \\
Univeres & $25.722 \mathrm{~cd}$ & $6+$ & $3.949 \mathrm{~b}$ & $7+$ & $15.33 \mathrm{c}$ & $5+$ \\
Esperanza & $24.592 \mathrm{e}$ & -10 & $3.785 \mathrm{c}$ & -1 & $15.36 \mathrm{c}$ & $6+$ \\
Yaman & $24.958 \mathrm{e}$ & -8 & $3.944 \mathrm{~b}$ & 2 & $15.80 \mathrm{~b}$ & $10+$ \\
Carola & $25.517 \mathrm{~d}$ & -3 & $4.021 \mathrm{ab}$ & $9+$ & $15.75 \mathrm{~b}$ & $9+$ \\
Oscarpoly & $26.434 \mathrm{a}$ & $9+$ & $3.839 \mathrm{c}$ & 1 & $14.50 \mathrm{~d}$ & -2 \\
Panther & $26.191 \mathrm{ab}$ & $10+$ & $3.840 \mathrm{c}$ & 2 & $14.64 \mathrm{~d}$ & -1 \\
Farida & $25.930 \mathrm{bc}$ & $8+$ & $3.824 \mathrm{c}$ & 0 & $14.73 \mathrm{~d}$ & 0 \\
\hline
\end{tabular}
$\begin{array}{lllllll}\text { Farida } & 25.930 \mathrm{bc} & 8+ & 3.824 \mathrm{c} & 0 & 14.73 \mathrm{~d} & 0\end{array}$ $\begin{array}{lllllll}\text { General mean } & 25.506 & \Sigma Y S i / t & 3.909 & \Sigma Y S i / t & 15.32 & \Sigma Y S i / t\end{array}$

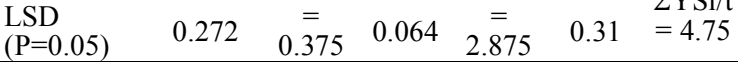
Ysi = Yield stability statistics, Select genotypes with YSi $>$ the mean $\Sigma \mathrm{YSi} / \mathrm{t}+=$ Selected genotype stability.

*and** significant at the 0.05 and 0.01 levels of probability, respectively

Means with the same letters has not significant differences at 0.05 levels of probability

Also, the data in Table 8 show that selection could be achieved and the studied genotypes in corrected sugar yield/fed and corrected sugar $\%$, and three genotypes Cesira, Univeres, and Carola, could be accepted because $\mathrm{YS}_{\mathrm{i}}$ values of them are bigger than grand means of the eight varieties, while Esperanza and Yaman genotypes which were unstable because their values in corrected sugar yield/fed were smaller than grand means and $\mathrm{YS}_{\mathrm{i}}<\Sigma \mathrm{YSi} / \mathrm{t}$. The superiority in these varieties may be due to stable in their genetic potentials (genetically stable) and unaffected by environmental conditions (phenotypic stable) under this study. Similar results were obtained by those of Aly, 2006; Shalaby, et al. 2007 and Al-Jbawi, et al. 2016.

\section{CONCLUSION}

Under this work, it could be recommended that Oscar poly and Panther as well as Farida are high yielding in root yield and are preferred in early sowing on early October as possible, while Cesira and/or Carola varieties are better in corrected sugar\%, across locations. Regarding genotypes performance and yield stability parameter, it was concluded that Oscar poly, Panther and Farida genotypes were judged as the most ideal for high and stable root yield. Meanwhile, Cesira, Univeres and Carola are judged the most suitable for high and stable sugar yield and were useful for manufactory proprieties budget and quality.

\section{REFFRENCES}

A.O.A.C. (2005). Association of official analytical chemists. Official methods of analysis, $26^{\text {th }} \mathrm{Ed}$. AOAC International, Washington, D.C; USA. 
Al-Jbawi, E.; A.F. Al Raei,; A. Al Ali and H. Al Zubi (2016). Genotype-Environment interaction study in sugar beet (Beta vulgaris L.). Inter. J. Env., 5(3): 74-86.

Al-Labbody, A.H.S. (2012). Performance of some sugar beet varieties under different sowing dates. Fayoum J. Agric., Res., \& Dev., 26 (1): 86 -92.

Aly, E.F.A. (2006). Effect of environmental conditions on productivity and quality of some sugar beet varieties. Ph.D. Thesis, Fac., Agric., Benha Univ.

Brown, J.D. and O. Lilliand (1964). Rapid determination of potassium and sodium in plant material and soil extracts by Flamphotometry. Proc. Amer. Soc. Hort. Sci., 48: 341-346.

Carruthers, A.; J.F.T. Oldfield and H.J.Teague (1962). Assessment of beet quality. Paper Presented to the $15^{\text {th }}$ Annual Technical Conference, British Sugar Corporation LTD. 36pp.

Cooke, D.A. and R.K. Scott (1993). The Sugar Beet Crop. Science Practice. Puplished by Chapman and Hall, London. pp: 262-265.

Ghareeb, Zeinab, E.; Hoda E.A. Ibrahimm and S.R.E. El-Sheikh (2013). Statistical and genetical evaluation of fifteen sugar beet genotypes under three sowing dates. Egypt., J. Plant Breed., 17 (5): $69-81$

Gomez, K.A. and A.A. Gomez (1984). Statistical Procedures For Agricultural Research. A WileyInter-Science Publication, John Wiley and Sons, New York.

Hossain, Ferdous M.D.; Qazi, Abdul Khaliq and Abdul Karim (2015). Effect of sowing dates on growth and yield of tropical sugar beet. Inter., J. Agron., \& Agric., Res., (IJAAR), 7(1):53-60.

Hozayn, M.; A. A. Abd El-Monem and A. A. Bakery (2013). Screening of some exotic sugar beet cultivars grown under newly reclaimed sandy soil for yield and sugar quality traits. J. Appl. Sci. Res., 9 (3): 2213-2222.

Kaloi, G.M.; A.H.Mari,; M. Zubair; R.N. Panhwar; N. Bughio; S. Junejio; G.S. Unar and M.A. Bhutto (2014). Performance of exotic sugar beet varieties under agr-climatic conditions of lower Sindh. J. Anim. Plant Sci., 24(4): 1135-1140.

Kang, M. S.; D. P. Gorman and H. N. Pham (1991). Application of a stability statistic to international maize yield trials. Theor.: Appl. Genet, 81: 162165. http://dx.doi.org/10.1007/BF00215718
Kang, M.S. and R. Magari (1995). Stable a BASICA program for calculating stability and yield stability statistics. Agron., J., 87: 276-277.

Khalil, Soha R. A. (2010). Study of performance and behavior of some sugar beet varieties under different environmental conditions. Ph.D. Thesis, Fac. Of Agric.. Fayoum Univ. Egypt.

Kristek, A.; I. Liovic and Z. Magud (1997). Economic value of sugar beet varieties in investigation in the Slavonic region. Poljorivreda, 3(2) 21-30. (C.F. CAB computer system).

Mahdi, Naghizadeh; Ali, Ali-Askari and Ali Fadaie (2013). Study of effect of sowing and harvest date on sugar beet quantity and quality traits. Inter. J. Agron.\&Plant Prod., 4(12): 3392-3395

Nasr, M.I. and A.M. Abd El-Razek (2008). Sugar beet performance under newly reclaimed soils conditions of Sinai Egypt. Sugar Tech., 10(3): 210-218

Ntwanai, B. and S.W. Tuwana (2013). Effect of planting date on yield and sugar content of sugar beet cultivars grown in Cradock, Eastern Cape. African Crop Sci., Conf., Proc., 11: 51 - 54.

Petkeviciene, B. (2009). The effect of climate factors on sugar beet early sowing timing. Agron., Res., 7 (Special issue I): 436-443

Piper, C.S. (1955). Soil and plant analysis. Univ. of Adelaide, Australia, P.178

Ramazan, C. (2002). Root yield and quality of sugar beet in relation to sowing date, plant population and harvesting date interactions. Turk, J. Agric. 26: $133-139$

Shalaby, N.M.S. (2003). Effect of environmental conditions on the behavior of different genotypes of sugar beet for root yield and quality. Ph.D. Thesis, Fac. Agric. Al-Azhar Univ., Egypt.

Shalaby, N.M.S.; I.E El-Beially; A.H.S.Al-Labbody and S.H.M. Abd-El- Haleem (2007). Studies on stability of sugar beet genotypes under old and new reclaimed lands. Pakistan. J. Biotechnol., 4 (1-2): 73 -91.

Snedecor, G.W. and W.G. Cochran (1981). Statistical methods $6^{\text {th }}$ Ed. Iowa State Univ. Press. Ames. Iowa. USA.

Walter, R. Fehr (1987). Principles of cultivar development, volume 1 theory and technique. Macmillan Publishing Company. A division of Macmillan, Inc., New York, Collier Macmillan Publishers London, Chapter Eighteen:247-255.

\footnotetext{
تقيم حاصل وجودة وثبات بعض أصناف بنجر السكر وعلاقتها بمواقع و مواعيد الزراعة إعلة

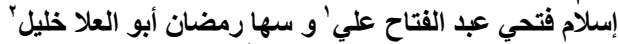

